\title{
FIRST RECORD OF NUBENSIA NUBENS (EDWARDS, 1929) (DIPTERA: CHIRONOMIDAE) FROM CROATIA
}

\section{Valentina Dorić ${ }^{1}$, Miran Koh ${ }^{2} \&$ Zlatko Mihaljević $^{3}$}

\author{
${ }^{1}$ Eko-monitoring Ltd., Kučanska 15, 42000 Varaždin, Croatia \\ ${ }^{2}$ Department of Biology, Josip Juraj Strossmayer University of Osijek, Cara Hadrijana 8A, \\ 31000 Osijek, Croatia \\ ${ }^{3}$ Department of Biology, Faculty of Science, University of Zagreb, Rooseveltov trg 6, \\ 10000 Zagreb, Croatia
}

Dorić, V., Koh, M. \& Mihaljević, Z.: First record of Nubensia nubens (Edwards, 1929) (Diptera: Chironomidae) from Croatia. Nat. Croat., Vol. 29, No. 1, 139-142, Zagreb, 2020.

The species Nubensia nubens (Edwards, 1929) from the dipteran family Chironomidae has been recorded for the first time in Croatian chironomid fauna. It was found in the littoral of the oligotrophic Lake Vrana on the island of Cres. The species is known from Italy, Albania and the Republic of Northern Macedonia as well as western Europe, the Czech Republic and the Pyrenees. Lake Vrana is currently the only known habitat of this species in Croatia.

Key words: Nubensia genus, new species, chironomid larvae, Adriatic island lake

Dorić, V., Koh, M. \& Mihaljević, Z.: Prvi nalaz vrste Nubensia nubens (Edwards, 1929) (Diptera: Chironomidae) u Hrvatskoj. Nat. Croat., Vol. 29, No. 1, 139-142, Zagreb, 2020.

Vrsta Nubensia nubens (Edwards, 1929) koja pripada porodici Chironomidae zabilježena je po prvi puta u fauni Hrvatske. Pronađena je u litoralu Vranskog jezera na otoku Cresu. Ova vrsta je poznata u fauni Italije, Albanije te Republike Sjeverne Makedonije, kao i s područja zapadne Europe, Češke i Pirineja. Vransko jezero na otoku Cresu zasad je jedino poznato stanište ove vrste u Hrvatskoj.

Ključne riječi: rod Nubensia, nova vrsta, ličinke trzalaca, jezero na jadranskom otoku

\section{INTRODUCTION}

There are currently more than 6500 described species belonging to the family Chironomidae, making it one of the most successful Dipteran families to inhabit freshwater habitats (Armitage et al., 1995). Chironomids can be found at elevations of up to $5600 \mathrm{~m}$ a.s.l. on Himalayan glaciers, in Lake Baikal at a depth of $1600 \mathrm{~m}$, in Antarctica where they are the only living insects, as well as in caves where they are only known flying troglobionts (Armitage et al., 1995; Andersen et al., 2016).

Nubensia nubens (Edwards, 1929) is currently the only species belonging to the genus Nubensia Spies, proposed by Spies \& DetTinger-KLemm (2015) based on the morphological characteristics of larvae, pupae and both adult male and female. In the latest version of the Fauna Europaea database the species is still listed as Polypedilum (Pentapedilum) nubens (Edwards, 1929) (SAETHER \& SPIES, 2013). It is also worth mentioning that the species can be identified as Polypedilum type A in Brooks et al. (2007). The species is currently known to inhabit western Europe, the Czech Republic, Spain, Portugal, Italy, the Republic of North Macedonia and Albania (SAether \& Spies, 2013; Bituší́ \& Trnkové, 2019). 


\section{MATERIALS AND METHODS}

This study was conducted in the littoral zone of Lake Vrana on Cres Island. This is an ultra-oligotrophic karstic lake with an area of $5.75 \mathrm{~km}^{2}$ and an approximate depth of $50 \mathrm{~m}$ (Tомес et al., 2002).

The samples were taken on one occasion in July 2018 following the standard lake littoral sampling protocol (Urbanič et al., 2012). Three locations (Fig. 1) were sampled and at each location ten replicates were collected up to one $\mathrm{m}$ depth, using a benthic hand net $(25 \times 25 \mathrm{~cm}$ area, $500 \mu \mathrm{m}$ mesh-size). Samples were taken in microhabitats covering at least $10 \%$ of the area, proportionately to their coverage at the sampling sites.

Chironomidae larvae were collected together with all other benthic taxa, separated in the lab and identified to the species level using VAllenduuk (2017) and Spies \& Dettinger-Klemm (2015). Seven larvae are deposited as semi-permanent microscopic slides and the rest are deposited in $80 \%$ ethanol at the Department of Biology, Faculty of Science in Zagreb. Photographs of the head capsule parts were taken using a Canon EOS 550D camera and a Carl Zeiss Microscope Axio Vert.A1, magnification 400x. Habitus photograph was taken using the same camera and Carl Zeiss Stemi 2000-C Stereo Microscope, magnification 40x.

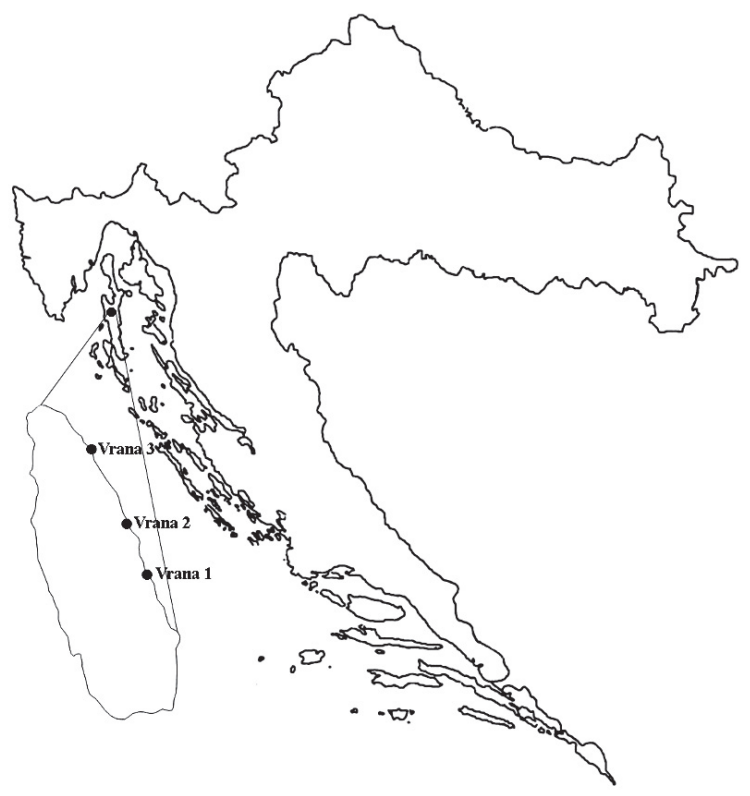

Fig. 1. Position of Lake Vrana and three sampling locations of Nubensia nubens (Edwards, 1929).

\section{RESULTS AND DISCCUSSION}

A total of 176 Chironomidae individuals belonging to 11 taxa were collected in Lake Vrana. In total 57 larvae belonging to the species Nubensia nubens (Fig. 2) were found at locations 1 and 2 but none were found at location 3. At location 1 larvae of N. nubens comprised $46 \%$ of the chironomid community and $69 \%$ at location 2 . 

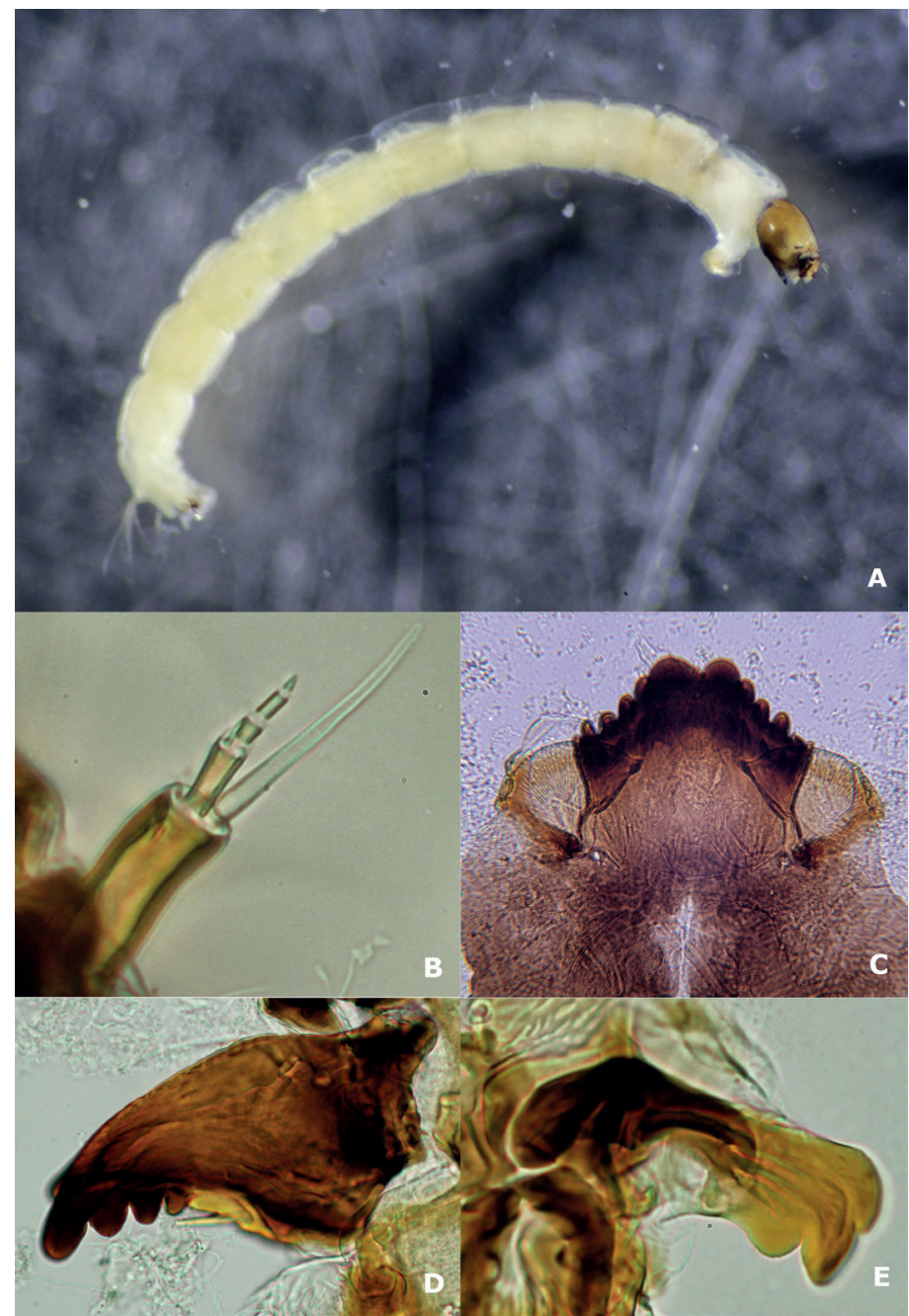

Fig. 2. Nubensia nubens (Edwards, 1929) larva. A) Habitus. B) Antenna. C) Mentum and ventromental plates. D) Mandible. E) Premandible.

The locations differed in the substrate composition in the littoral of the lake. The substrate at locations 1 and 2 was composed solely of meso- and macrolithal (stones sized 2-40 cm), and at location 3 it was composed of different sized stones $(0,2-40 \mathrm{~cm})$ and macrophyte vegetation. They also differed in the inclination of the littoral, the third location being gently inclined whereas locations 1 and 2 were steep.

According to Moller Pilot (2009) this species was found in waters with very low conductivity (less than $200 \mu \mathrm{S} / \mathrm{cm}$ ), but here it was found at a conductivity of $401 \mu \mathrm{S} /$ $\mathrm{cm}$, which is a result of karstic geology.

In the Czech Republic the species was found in the mesotrophic Vranov reservoir and the eutrophic reservoir Nove Mlyny (SyrovátKa \& LANGTon, 2015; SyrovátKa, personal communication) and in Albania it is known from Lake Ohrid (BITUŠíK \& TR- 
NKOvÁ, 2019). In the Rhine River, it was collected from an artificial oxbow lake (SpIES \& Dettinger-Klemm, 2015). During extensive research efforts, which included the sampling of seven natural and 36 man-made lakes from Croatia (Vilenica et al., 2019) the species N. nubens was found only in the oligotrophic Lake Vrana. Since the species was found in European lakes and reservoirs of different trophy one can conclude that it is a generalist species whose spread to other, similar, habitats in Croatia was stopped solely by the geographic positioning of the Lake Vrana.

The new record of $N$. nubens represents a valuable addition to Croatian Chironomidae fauna, which at the time, consisted of 235 species (ČERBA et al., 2020), but many more are expected. Lake Vrana on the island of Cres is the only known habitat of this species in Croatia so far.

\section{ACKNOWLEDGEMENTS}

We would like to thank Dr Marko Miliša, Natalija Vučković, Ivana Grgić and Mirjana Dimnjaković for their great help during fieldwork and separation of samples. We would also like to thank two anonymous reviewers for their helpful comments that improved this paper.

Received November 28, 2019

\section{REFERENCES}

Andersen, T., Baranov, V., Hagenlund, L. K., Ivković, M., Kvifte, G. M., \& Pavlek, M., 2016: Blind Flight? A New Troglobiotic Orthoclad (Diptera, Chironomidae) from the Lukina Jama - Trojama Cave in Croatia. PLoS ONE 11(4), e0152884. doi:10.1371/journal. pone.0152884

Armitage, P. D., Pinder, L. C. \& Cranston P. (Eds.), 1995: The Chironomidae, Biology and ecology of non-biting midges. Chapman \& Hall, London, UK.

Bitušík, P. \& Trnková, K., 2019: A preliminary checklist of Chironomidae (Diptera) from Albania with first records for the Balkan Peninsula. Zootaxa 4563 (2), 361-371.

Brooks, S. J., Langdon, P. G. \& Heiri, O. 2007: The identification and use of Palearctic Chironomidae larvae in paleontology. QRA Technical Guide No. 10, Quaternary Research Association, London. 276 pp.

Čerba, D., Koh, M., Ergović, V., Mihaljević, Z., Milošević, Dj., \& Hamerlík, L., 2020: Chironomidae (Diptera) of Croatia with notes on the diversity and distribution in various habitat types. Zootaxa 4780 (2), 259-274. doi: 10.11646/zootaxa.4780.2.2.

Moller Pillot, H. K. M., 2009: Chironomidae Larvae of the Netherlands and Adjacent Lowlands. Biology and Ecology of the Chironomini. KNNV Publishing, Zeist, The Netherlands, 270 pp.

Saether, O. A. \& Spies, M., 2013: Fauna Europaea: Chironomidae. In: Pape, T. \& Beuk, P. 2013: Fauna Europaea: Diptera. Fauna Europaea version 2017.06, https://fauna-eu.org

Spies, M. \& Dettinger-Klemm, A., 2015: Diagnoses for Nubensia, n. gen. (Diptera, Chironomidae, Chironomini), with the first full descriptions of the adult female and larva of N. nubens (Edwards, 1929). Zootaxa 3994 (1), 109-121.

SyrovátKa, V. \& LANGton, P. H., 2015: First records of Lasiodiamesa gracilis (Kieffer, 1924), Parochlus kiefferi (Garrett, 1925) and several other Chironomidae from the Czech Republic and Slovakia. CHIRONOMUS Journal of Chironomidae Research 28, 45-56.

Tomec, M., Ternjej, I., Kerovec, M., Teskeredžić, E. \& Meštrov, M., 2002: Plankton in the oligotrophic Lake Vrana (Croatia). Biologia, Bratislava 57/5, 579-588.

Urbanič, G., Petкovska, V. \& Pavlin Urbanič, M., 2012: The relationship between littoral benthic invertebrates and lakeshore modification pressure in two alpine lakes. Fundamental and Applied Limno$\log \mathbf{1 8 0} / \mathbf{2}, 157-173$.

Vallenduuk, H. J., 2017: Chironomini larvae of western European lowlands (Diptera: Chironomidae). Keys with notes to the species. Lauterbornia 82, 1-216.

Vilenica, M., VučKović, N. \& Mihaljević, Z., 2019: Littoral mayfly assemblages in South-East European man-made lakes. Journal of Limnology 78, 47-59. doi: 10.4081/jlimnol.2019.1853 